\title{
UPAYA MENGEMBANGKAN KEMAMPUAN BAKAT MELALUI \\ LAYANAN BIMBINGAN KARIR DENGAN STRATEGI PROBLEM SOLVING PESERTA DIDIK KELAS X IPS.2 SMA NEGERI 18 \\ PALEMBANG
}

\author{
Yusfandaria \\ Guru SMA Negeri 18 Palembang \\ Email: yusfandaria@gmail.com
}

\begin{abstract}
ABSTRAK
PTK Konseling ini dilaksanakan dengan tujuan untuk mengetahui kemampuan mengenal bakat siswa melalui layanan Bimbingan Karir dengan strategi Problem Solving peserta didik kelas X IPS 2 SMA Negeri 18 Palembang. Perencanaan ini dilakukan selama tiga bulan dari Februari s/d April 2017 semester genap tahun pelajaran 2016/2017. Subjek penelitian sebanyak 30 orang. Dilaksanakan pada tugas perkembangan "mengenal kemampuan, bakat, minat serta arah kecendrungan karir dan aspirasi seni". Ditambah satu orang guru sebagai kolaborator. Berdasarkan hasil penelitian yang telah dilakukan, terlihat adanya peningkatan kemampuan belajar siswa dari siklus I ke siklus II.
\end{abstract}

Kata kunci: BK, Layanan Bimbingan Karir, Strategi Problem Solving

\section{EFFORTS TO DEVELOP TALENT ABILITY THROUGH CAREER BIMBING SERVICES WITH PROBLEM SOLVING STRATEGIES PARTICIPANTS IN X IPS.2 SMA NEGERI 18 PALEMBANG}

\begin{abstract}
Counseling was carried out with the aim of knowing the ability to recognize students' talents through Career Guidance services with a strategy of Problem Solving students in class X IPS 2 SMA Negeri 18 Palembang. This planning is carried out for three months from February to April 2017 even semester 2016/2017. The research subjects were 30 people. Performed in the development task "to recognize the abilities, talents, interests and direction of career trends and artistic aspirations". Added one teacher as a collaborator. Based on the results of the research that has been done, it can be seen that there is an increase in student learning abilities from cycle I to cycle II.
\end{abstract}

Keywords: BK, Career Guidance Service, Problem Solving Strategy

\section{PENDAHULUAN}

Bakat adalah bawaan, given from God, dan bakat adalah sesuatu yang dilatih. Sebelum memahami beberapa definisi dan pendekatan bakat yang juga diungkapkan beberapa ahli, ada baiknya kita yakini satu hal: yakin dan percayalah bahwa setiap insan di muka bumi ini telah memiliki bakat berupa anugerah dari 
Sang Maha Kuasa. Beberapa istilah kerap dipakai ketika berbicara bakat secara spesifik, antara lain aptitude, talent/talenta, intelligence/inteligensi/kecerdasan, gifted/giftedness, dan sebagainya. Pada dasarnya istilah-istilah tersebut membawa makna bakat yang berkembang sesuai kebutuhan dan kepentingan. Namun samasama mengandung unsure bakat bawaan dan latihan. Misalnya yang dikemukakan oleh KBBI On line, menurut Kamus Besar Bahasa Indonesia (KBBI) Bakat merupakan dasar "kepandaian, sifat dan pembawaan" yang dibawa sejak lahir.

Jadi apabila seseorang terlahir dengan suatu bakat khusus, jika dididik dan dilatih, bakat tersebut dapat berkembang dan dimanfaatkan secara optimal. Sebaliknya jika dibiarkan saja tanpa pengarahan dan penguatan, bakat itu akan mati dan tak berguna. Bakat sangat kecil sekali kemungkinannya untuk berubah. Baat itu adalah relatif tetap sepanjang waktu tertentu. Karena bakat itu relatif stabil, maka bakat-bakat itu dapat digunakan untuk membantu keberhasilan dalam bidang kependidikan dan karir. Dengan demikian dapatlah dikatakan bahwa: bakat mengungkap potensi untuk mempelajari suatu aktifitas tertentu, bakat relatif berbeda, bakat relatif konstan.

Salah satu permasalahan yang banyak terjadi dikalangan para peserta didik di SMA Negeri 18 Unggulan Palembang adalah ketidakmampuan dalam mengenal kemampuan, bakat, dan minta serta arah kecendrungan karir dan aspirasi seni. Kondisi ini menggambarkan lemahnya siswa dalam mengembangkan kebiasaan-kebiasaan belajar sebagai mengembangkan bakat. Bimbingan dan Konseling memiliki peranan penting dalam membantu menangani permasalahan peserta didik, salah satunya adalah permsaalahan mengembangkan bakat peserta didik. Penanganan masalah-masalah peserta didik yang berkaitan dengan mengembangkan bakat tersebut perlu mengubah atau memperbaiki pendekatan konseling yang selama ini berlangsung dengan mengubah yang bersifat pendekatan diadik (pendekatan langsung) dengan pendekatan triadik (melalui pendekatan perantara).

Layanan bimbingan karier diartikan sebagai bimbingan yang bertujuan membantu siswa menyusun rencana karier dan menyiapkan diri untuk kehidupan kerja (Munandir, 2001:77). Menurut pendapat Muhammad Thayeb Manrihu, (2000:18), layanan bimbingan karier adalah: "suatu perangkat, lebih tepatnya 
suatu program yang sistematik, proses-proses, teknik-teknik, atau layanan-layanan yang dimaksudkan untuk membantu individu memahami dan berbuat atas dasar pengenalan diri dan pengenalan kesempatan-kesempatan dalam pekerjaan, pendidikan, dan waktu luang, serta mengembangkan keterampilan-keterampilan mengambil keputusan sehingga yang bersangkutan dapat menciptakan dan mengelola perkembangan kariernya."

Berdasarkan latar belakang yang telah dikemukakan diatas, maka rumusan masalah dalam penelitian ini adalah: "Apakah melalui penerapan dengan Strategi Problem Solving dapat mengembangan kemampuan mengenal bakat peserta didik kelas X.IPS.2 SMA Negeri 18 Unggulan Palembang?”.

Penelitian Tindakan Bimbingan Konseling ini dilaksanakan dengan tujuan untuk mengetahui kemampuan mengenal bakat melalui layanan Bimbingan Karir dengan strategi Problem Solving peserta didik kelas X.IPS.2 SMA Negeri 18 Unggulan Palembang. Ada beberapa devinisi bakat yang dikemukakan oleh para ahli diantaranya adalah: Bringham (2006) menjelaskan bakat adalah suatu kondisi atau serangkaian karakteristik atau kemampuan seseorang yang dengan suatu latihan khusus memeungkinkannya mencapai suatu kecakapan, pengetahuan dan ketrmpilan khusus, misalnya kemampuan berbahasa, kemampuan bermain music dan lain-lain.

Crow \& Crow dalam bukunya General Psychology sebagaimana dikutup oleh Nurkancana (2014:191), mengatakan bahwa:

Bakat adalah suatu kualitas yang Nampak pada tingkah laku manusia pada suat lapangan keahlian tertentu seperti music, seni mengarang, kecakapan dalam matematika, keahlian dalam bidang mesin, atau keahlian-keahlian lainnya. Secara umum bimbingan adalah istilah yang mencakup pengertian umum proses layanan bantuan kemanusian. Di latar sekolah, layanan bimbingan diberikan dengan tujuan untuk membantu siswa yang mengalami masalah, khususnya yang berkenaan dengan penyusunan rencana untuk masa depannya. Mengingat usia perkembangannya, kerisauan umum para siswa tersebut adalah mengenai pendidikannya (keberhasilan belajar, dan kelanjutan studi) dan pekerjaan apabila nanti tamat dari sekolah. 
Layanan bimbingan karier diartikan sebagai bimbingan yang bertujuan membantu siswa menyusun rencana karier dan menyiapkan diri untuk kehidupan kerja (Munandir, 2001:77). Menurut pendapat Muhammad Thayeb Manrihu, (2000:18), layanan bimbingan karier adalah:

"Suatu perangkat, lebih tepatnya suatu program yang sistematik, prosesproses, teknik-teknik, atau layanan-layanan yang dimaksudkan untuk membantu individu memahami dan berbuat atas dasar pengenalan diri dan pengenalan kesempatan-kesempatan dalam pekerjaan, pendidikan, dan waktu luang, serta mengembangkan keterampilan-keterampilan mengambil keputusan sehingga yang bersangkutan dapat menciptakan dan mengelola perkembangan kariernya." Layanan bimbingan karier adalah layanan bimbingan yang diberikan kepada sisiwa untuk dapat merencanakan dan mengembangkan masa depannya, berkaitan dengan dunia pendidikan maupun dunia karier (Hibana S. Rahman, 2003:43).

Sukardi (2000) menjelaskan bahwa secara umum Bimbingan Karir di sekolah khususnya Sekolah Menengah, bertujuan untuk membantu siswa dalam pemahaman dirinya dan lingkungannya, dalam pengambilan keputusan, perencanaan, dan pengarahan kegiatan-kegiatan yang menuju kepada karir dan cara hidup yang akan memberikan rasa kepuasan karena sesuai, serasi, dan seimbang dengan dirinya dan lingkungannya. Sedangkan tujuan khusus yang menjadi sasaran Bimbingan Karir di sekolah adalah, di antaranya: (a) agar siswa dapat meningkatkan pengetahuan tentang dirinya sendiri (self concept), (b) agar siswa dapat meningkatkan pengetahuannya tentang dunia kerja, (c) agar siswa dapat mengembangkan sikap dan nilai diri sendiri dalam menghadapi pilihan lapangan kerja serta dalam persiapan memasukinya, (d) agar siswa dapat meningkatkan keterampilan berpikir agar mampu mengambil keputusan tentang jabatan yang sesuai dengan dirinya dan tersedia dalam dunia kerja, (e) agar siswa dapat menguasai keterampilan dasar dalam pekerjaan terutama kemampuan berkomunikasi, bekerja sama, berprakarsa, dan sebagainya (Sukardi, 2000).

Problem solving adalah suatu proses mental dan intelektual dalam menemukan masalah dan memecahkan berdasarkan data dan informasi yang akurat, sehingga dapat diambil kesimpulan yang tepat dan cermat (Hamalik, 2014). Problem solving yaitu suatu pendekatan dengan cara problem 
identifikation untuk ketahap syntesis kemudian dianalisis yaitu pemilahan seluruh masalah sehingga mencapai tahap application selajutnya komprehension untuk mendapatkan solution dalam penyelesaian masalah tersebut. Pendapat lain Problem solving adalah suatu pendekatan dimana langkah-langkah berikutnya sampai penyelesaian akhir lebih bersifat kuantitatif yang umum sedangkan langkah-langkah berikutnya sampai dengan pengelesain akhir lebih bersifat kuantitatif dan spesifik (Qrustian Blogs Friendster.com).

Ini berarti oreantasi pembelajaran Problem solving merupakan infestigasi dan penemuan yang pada dasarnya pemecahan nasalah. Apabila solvingng yang diharapkan tidak berjalan sebagaimana yang diinginkan berarti telah terjadi di dalam tahap-tahap awal sehingga setiap enginer harus mulai kembali berfikir dari awal yang bermasalah untuk mendapatkan pemahaman menyeluruh mengenai masalah yang sedang dihadapi. Berpikir memecahkan masalah dan menghasilkan sesuatu yang baru adalah kegiatan yang kompleks dan berhubungan erat satu dengan yang lain. Suatu masalah umumnya tidak dapat dipecahkan tanpa berpikir, dan banyak masalah memerlukan pemecahan yang baru bagi orang-orang atau kelompok. Sebaliknya, menghasilkan sesuatu (benda-benda, gagasan-gagasan) yang baru bagi seseorang, menciptakan sesuatu, itu mencakup Problem solving. Ini berarti informasi fakta dan konsep-konsep itu tidak penting. Seperti telah kita ketahui, penguasaan informasi itu perlu untuk memperoleh konsep; keduanya itu harus diingat dan dipertimbangkan dalam Problem solving dan perbuatan kreatif. Begitu pula perkembangan intelektual sangat penting dalam Problem solving (Slameto, 2003).

\section{METODE PENELITIAN}

Penelitian ini dilakukan di SMA Negeri 18 Unggulan Palembang yang terletak di jalan Mayor Ruslan Palembang. Perencanaan penelitian dilakukan selama tiga bulan pada bulan Februari s/d April 2017 semester genap tahun ajaran 2016/2017. Subjek penelitian yaitu pada peserta didik kelas X.IPS.2 SMA Negeri 18 Unggulan Palembang, dengan jumlah peserta didik 30 orang. Penelitian dilaksanakan pada saat mata bimbingan konseling berlangsung dengan tugas perkembangan "mengenal kemampuan, bakat, minat serta arah kecendrungan 
karir dan aspirasi seni" dan ditambah satu orang guru yang berfungsi sebagai kolaborator (melakukan pengamatan perkembangan aktivitas belajar peserta didik dalam lembar observasi).

Penelitian Tindakan Bimbingan Konseling ini direncanakan terdiri dari 2 (dua) siklus. Setiap siklus dilaksanakan dengan perubahan yang ingin dicapai. Sebelum dilaksanakan tindakan, terlebih dahulu diberikan tes awal dengan maksud untuk mengetahui kemampuan awal peserta didik. Setiap siklus dalam penelitian ini meliputi prosedur berikut ini: (1) perencanaan, (2) pelaksanaan tindakan, (3) observasi dan (4) refleksi (Arikunto,2006).

\section{HASIL PENELITIAN DAN PEMBAHASAN}

\section{SIKLUS I}

\section{Rencana Tindakan}

a. Bertemu dengan teman sejawat/guru mitra, membicarakan tindakan yang akan dilakukan dalam penelitian.

b. Menyiapkan materi pelajaran yang akan diajarkan pada siklus I.

c. Menyiapkan instrumen penelitian (lembar observasi aktivitas peserta didik).

\section{Pelaksanaan Tindakan}

Sesuai dengan perencanaan yang telah disepakati bersama, peneliti bertindak sebagai pengajar sedangkan teman sejawat bertindak sebagai pengamat atau observer. Sebelum pelajaran dimulai peneliti memberitahukan kepada peserta didik bahwa dalam beberapa minggu kedepan peneliti yang akan memberikan bimbingan konseling di kelas X.IPS.2 SMA Negeri 18 Unggulan Palembang. Sebelum memasuki materi baru peneliti menanyakan kepada peserta didik materi sebelumnya, sesudah itu peneliti memberikan pengarahan kepada peserta didik bagaimana cara belajar kedepannya. Peneliti mengharapkan peserta didik bisa aktif dalam pembelajaran. 


\section{Observasi}

Selanjutnya akan ditayangkan rekapitulasi hasil nilai peserta didik siklus I

Tabel 1. Rekapitulasi Nilai Siklus I

\begin{tabular}{|c|l|c|}
\hline No & \multicolumn{1}{|c|}{ KATEGORI } & PERSENTASE \\
\hline A & $\begin{array}{l}\text { Peserta didik sangat berminat untuk } \\
\text { mengembangkan bakat-bakat yang ia miliki }\end{array}$ & 61,67 \\
\hline B & $\begin{array}{l}\text { Peserta didik tidak mempunyai } \\
\text { kesulitan/masalah pribadi }\end{array}$ & 64,17 \\
\hline C & $\begin{array}{l}\text { Tidak ada hambatan peserta didik dalam } \\
\text { pengembangan diri }\end{array}$ & 60,00 \\
\hline D & $\begin{array}{l}\text { Orang tua mampu untuk menyediakan } \\
\text { kesempatan yang peserta didik miliki }\end{array}$ & 63,33 \\
\hline
\end{tabular}

Berdasarkan tabel 1 di atas Anak sangat berminat untuk mengembangkan bakat-bakat yang is miliki dari 30 peserta didik persentase untuk kaegori ini sebedar 61,67\%, untuk penilaian peserta didik tidak mempunyai kesulitan/masalah pribadi sebesar 64,17\%, Tidak ada hambatan Siswa dalam pengembangan diri sebesar $60,00 \%$, Orang tua mampu untuk menyediakan kesempatan yang siswa miliki sebesar 63,33\%.

\section{Refleksi}

Berdasarkan hasil pengamatan pada siklus I terjadi beberapa peningkatan beberapa kemampuan peserta didik namun karena aktivitas peserta didik belum meningkat sesuai dengan yang diharapkan peneliti akan merubah dan menambah tindakan pada pertemuan selanjutnya di siklus II yaitu dengan cara memberikan kisi-kisi uji kemampuan yang akan dipelajarai peserta didik pada pertemuan selanjutnya dan akan memberikan penghargaan kepada peserta didik yang aktif serta serta Konselor akan lebih terampil dan bersemangat dalam memotivasi peserta didik sehingga peserta didik bisa lebih antusias.

\section{SIKLUS II}

\section{Rencana Tindakan}

Berdasarkan refleksi pada siklus I, maka tindakan yang akan dilakukan pada siklus II adalah:

a. Menyiapkan materi pelajaran yang akan diajarkan pada siklus II. 
b. Menyiapkan instrumen penelitian (lembar observasi aktivitas peserta didik).

\section{Pelaksanaan Tindakan}

Kegiatan yang dilakukan pada siklus kedua sama yang dilakukan pada siklus pertama. Ada beberapa perubahan:

a. Memberikan bahan yang akan dipelajarai peserta didik pada pertemuan selanjutnya.

b. Memberikan pengahargaan bagi grup pesera didik yang paling aktif pada akhir pembelajaran.

\section{Observasi}

. Tabel 2. Rekapitulai Nilai Siklus II

\begin{tabular}{|c|c|c|c|c|c|c|}
\hline & A & B & C & D & E & F \\
\hline JUMLAH & 96 & 97 & 88 & 90 & 96 & 95 \\
\hline$\%$ & 80,00 & 80,83 & 73,33 & 75,00 & 80,00 & 79,17 \\
\hline
\end{tabular}

Berdasarkan tabel 2 di atas aktivitas peserta didik mampu memahami belajar secara optimal dengan memperhatikan faktor -faktor yang mempengaruhi belajar sebesar $80,00 \%$, mampu menerapkan nilai-nilai dan bertingkah laku sosial dalam kehidupan sehari-hari dengan kelompok sebaya sebesar 80,83\%, mampu memahami macam-macam kaidah ajaran agama sebesar 73,33\%, mampu mempraktekkan kegiatan yang mengarah kepengembangan karir menurut ajaran Agama sebesar 75,00\%, mampu memahami dan menerapkan pengembangan karirterhadap kegiatan belajar sebesar 80,00\%, mampu mengarahkan kemampuan bakat dan minat untuk pilihan karir sebesar 79,17\%.

\section{Refleksi}

Pada tahap ini akah dikaji apa yang telah terlaksana dengan baik maupun yang masih kurang baik dalam proses belajar mengajar dengan penerapan belajar aktif. Dari data-data yang telah diperoleh dapat duraikan sebagai berikut:

a. Berdasarkan data hasil pengamatan diketahui bahwa peserta didik aktif selama proses belajar berlangsung.

b. Kekurangan pada siklus-siklus sebelumnya sudah mengalami perbaikan dan peningkatan sehingga menjadi lebih baik. 
c. Hasil belajar siswsa pada siklus II mencapai ketuntasan.

\section{PEMBAHASAN}

Tabel 3. Hasil Uji Kemampuan Siklus I Dan Siklus II

\begin{tabular}{|c|c|c|c|c|}
\hline \multirow{2}{*}{ PERTEMUAN } & \multicolumn{4}{|c|}{ PREDIKAT } \\
\cline { 2 - 5 } & A & B & C & D \\
\hline SIKLUS I & 4 & 7 & 7 & 12 \\
\hline SIKLUS II & 5 & 22 & 3 & 0 \\
\hline
\end{tabular}

Tabel 3 di atas menjelaskan bahwa pada siklus I terdapat 4 orang peserta didik mendapatkan nilai A, 7 peserta didik mendapat nilas B dan 7 orang peserta didik mendapat nilai C, 12 peserta didik mendapat nilai D. Sedangkan pada siklus II terdapat 5 peserta didik mendapat nilai A, 22 peserta didik mendapat nilai B dan 3 peserta didik mendapat nilai C. Berikut ini dapat di lihat secara jels peningkatan yang terjadi di kelas X.IPS.2 SMA Negeri 18 Unggulan Palembang dalam mengenal bakat melalui bimbingan karir dengan strategi Problem Solving.

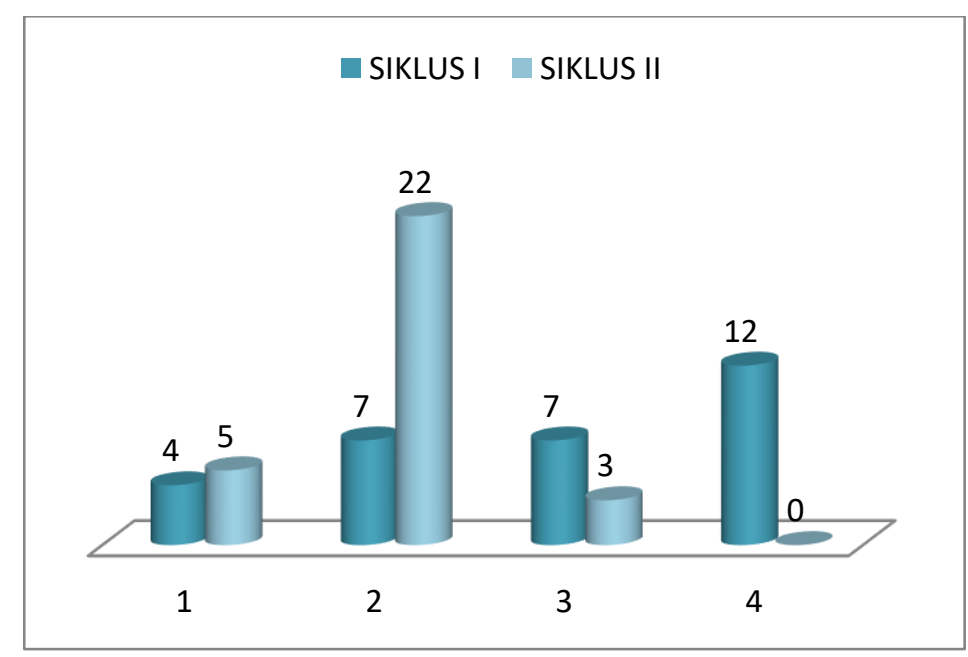

Gambar 1. Persentase Kemampuan Siklus I dan Siklus II

\section{SIMPULAN}

Berdasarkan hasil penelitian yang telah dilakukan tentang upaya meningkatkan kemampuan mengenal bakat dan minat dalam bimbingan konseling melalui layanan Bimbingan Karir strategi Problem Solving peserta didik kelas 
X.IPS.2 SMA Negeri 18 Unggulan Palembang memperlihatkan adanya peningkatan kemampuan bakat dalam bimbingan konseling peserta didik yang terlihat dari kemampuan belajar meningkat dari siklus I ke siklus II. Bagi guru mata pelajaran yang masih menggunakan metode ceramah dalam menyampaikan pelajaran konseling, sebaiknya dapat menggunakan layanan Bimbingan Karir strategi Problem Solving sebagai salah satu alternatif dalam proses penyampaian pembelajaran disekolah. Menghimbau para rekan guru untuk mengadakan tindakan penelitian kelas sesuai dengan mata pelajaran yang diajarkan untuk memecahkan masalah yang dihadapi peserta didik dalam belajar dan menghasilkan peserta didik yang berkualitas.

\section{DAFTAR PUSTAKA}

Arikunto, S. 2006. Metode Penelitian Kualitatif. Jakarta: Bumi Aksara

Bringham. 2006. Dasar-Dasar Manajemen Keuangan. Edisi 10. Salemba Empat. Jakarta.

Hamalik, Oemar. 2014. Media Pendidikan. Bandung: Penerbit PT Citra Adityawarman

Hibana S. Rahman. 2003. Bimbingan dan Konseling Pola 17. Yogyakarta UCY Press.

KBBI Online. https://kbbi.web.id/bakat diakses 20 Maret 2017

Ketut, Sukardi Dewa. 2011. Pengantar Pelaksanaan Program Bimbingan dan. Konseling di Sekolah. Jakarta: Rineka Cipta.

Munandir. 2001. Program Bimbingan Karier. Jakarta: Departemen Pendidikan

Najib, Aminuddin, et.all., 1997, Bahan Pelatihan Bimbingan Konseling di Sekolah Berdasarkan Kurikulum 1994 pola 17, Yogyakarta: Tim Instruktur Bimbingan Konseling DIY

Nurkancana, W. 2014. PemahamanIndividu. Surabaya: Usaha Nasional.

Slameto, 2003. Proses Belajar Mengajar Dalam Sistem Kredit (SKS). Penerbit Bumi Aksara: jakarta.

Sukardi, Dewa Ketut. 2000. Pengantar Pelaksanaan Program Bimbingan Dan Konseling Di Sekolah. Jakarta: Rineka Cipta.

Thayeb Manrihu. 2000. Tehnik dan Laboratorium Konseling. Jakarta: Dirjen Pendidikan Tinggi Depdikbud. 